\title{
Continuous Production of Vineqar Using Bioreactor with Supports of Porous Ceramics
}

\author{
Mitsuro TAKada* and Takeshi Hiramitsu* \\ *Gifu Prefectural Industrial Research Technical Center, 47 Kitaoyobi, \\ Kasamatsu-cho, Hashima-gun, Gifu 501-61
}

\begin{abstract}
A bioreactor consisting of 2 columns of porous ceramics, onto which Acetobacter aceti IFO-3284 was adsorbed, was applied to the continuous production of vinegar from a synthetic medium containing ethanol or from Unshu mandarine orange wine. The bioreactor was operated under either open or closed condition with the synthetic medium containing varying amount $(4.28 \sim 8.80 \%(\mathrm{w} / \mathrm{v}))$ of ethanol. The maximum concentrations of the acetic acid obtained were $8.10 \%$ from $8.41 \%(\mathrm{w} / \mathrm{v})$ under the open condition, and $8.39 \%$ from $7.24 \%(\mathrm{w} / \mathrm{v})$ under the closed condition. The maximum conversion ratios of acetic acid from ethanol were $81.1 \%$ under the open condition, and $98.3 \%$ under the closed condition with the synthetic medium. Using the bioreactor, the vinegar without problem in taste and flavor was obtained from Unshu mandarine orange wine under the closed condition. The amount of supply of oxygen under the closed condition was enough to oxidize ethanol in the substrate.
\end{abstract}

Continuous production of vinegar in a bioreactor with immobilized acetic acid bacteria has been widely studied ${ }^{1)}$. Entrapping the bacteria into gel beads were tried at first $^{2) 3)}$.

Recently, adsorption-methods are more of ten tried because acetic acid fermentation needs obligatory oxygen and its supply to the bacteria is easy in these methods ${ }^{4) 5)}$. We have earlier developed a column-typed bioreactor for aerobic fermentation, in which microorganisms are adsorbed onto porous ceramics supports $^{6)}$.

This bioreactor can be operated under the completely closed condition when oxygen necessary for the fermentbtion is supplied.

In this study, we tried to produce vinegar from a synthetic medium containing ethanol or from Unshu mandarine orange wine using this bioreactor for the purpose of elevating both acetic acid yield and acetic acid concentration in the vinegar (above $4.5 \%$ ) in as short time as possible.

\section{Materials and Methods}

\section{Microorganism and media}

Acetobacter aceti (IFO-3284) was used throughout the study. Bacterial cells were grown in the preculture-medium containing $10 \mathrm{~g}$ of glucose, $10 \mathrm{~g}$ of peptone, $10 \mathrm{~g}$ of yeast extract, $32 \mathrm{~g}$ of ethanol, and $10 \mathrm{~g}$ of acetic acid (per liter). The synthetic medium for the production of vinegar was composed of $15 \mathrm{~g}$ of glucose, $5 \mathrm{~g}$ of yeast extract, $2 \mathrm{~g}$ of pectin, $0.1 \mathrm{~g}$ of glycerin, and 43 to $88 \mathrm{~g}$ of ethanol (per liter).

Experimentally processed Unshu mandarin orange wines at the ethanol concentration between 4.72 and $6.00 \%(\mathrm{w} / \mathrm{v})$ were also used for the vinegar production.

The orange wines were brewed from Unshu mandarin orange juice added with glucose by use of "No. 1 wine yeast" (The Brewing Society of Japan) ${ }^{7}$.

\section{Design of bioreactor}

The outline of the bioreactor is shown in Fig. 1. This bioreactor consisted of two 3litter acryl resin vessels ${ }^{6}$. The supports for 
microorganism was composed of 6 units of porous ceramics. Its physical characteristics are shown in Table 1. Each vessel contained three units of porous ceramics as the supports for microorganism and was aerated by an air pump(Iwaki BA-230F).

When the bioreactor was operated un'der the closed condition, the oxygen concentration was maintained at $20.3 \%+2.0 \%$ by supplying oxygen from an oxygen-cylinder through an electromagnetic valve under the control of an

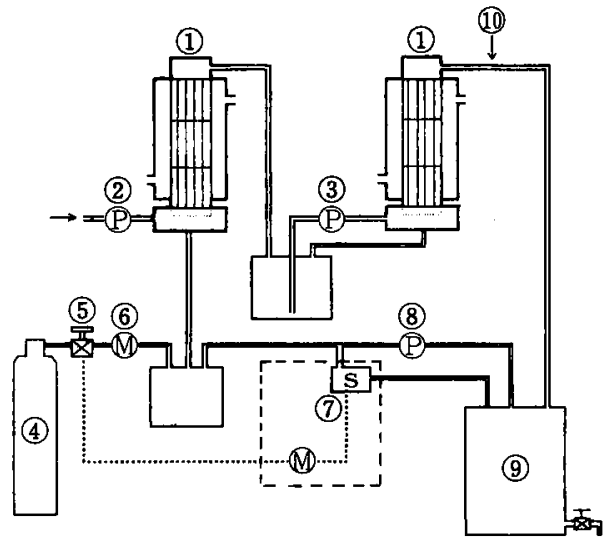

Fig. 1 Schematic diagram of the bioreactor*

(1) column

(2) metering pump (Iwaki EX-A 10)

(3) peristaltic pump (4) oxygen cylinder

(5) electromagnetic valve

(6) How meter (7) oxygen sensor

(8) air pump (9) tank

(10) sampling position

* When operated under open condition, the electromagnetic valve is closed and the part encircled by dotted line is removed. oxygen-sensor with membrane of galvanic of cell type (Iijima Electronic Co.) and the oxygen flow rate was regulated by a thermal mass flow meter (Estec SEF-51).

Immobilization of microorganism

Cells grown in $300 \mathrm{~m} l$ preculture-medium for 36 hours at $30^{\circ} \mathrm{C}$, together with $1000 \mathrm{ml}$ of the synthetic medium contaning $4.8 \% \quad(\mathrm{w} / \mathrm{v})$ ethanol, were poured into the bioreactor. And, succeeding three days aeration $(5 \mathrm{l} / \mathrm{min}$ ) could immobilize the microorganism to the ceramics supports.

Continuous production of vinegar under the open condition

Continuous production of vinegar from the synthetic medium (ethanol concentration : 4.73 $\sim 8.80 \%(\mathrm{w} / \mathrm{v}))$ was carried out under the open condition. The air supply was controlled at $5 \mathrm{l} / \mathrm{min}$. The temperature was kept at $30^{\circ} \mathrm{C}$. The average residence time of supplied liquid was regulated at 36 hours.

Continuous production of vinegar under the closed condition

The continuous production of vinegar from synthetic medium(ethanol concentration : 4.28 $27.48 \%(\mathrm{w} / \mathrm{v}))$ as well as from Unshu mandarin orange wine was carried out under the following operational conditions.

Air circulation was controlled basically at $5 \mathrm{l} / \mathrm{min}$.

The oxygen concentration in the gas phase was adjusted to be $20.3 \%+2.0 \%$. The flow rate of liquid was adjusted so that the average residence time of the liquid was held at 36 or 48 hours for the synthetic medium, and 27 or 40 hours for Unshu mandarine orange wine. The temperature was kept at $30^{\circ} \mathrm{C}$.

Table 1 Physical characteristics of the ceramics for immobilization of microorganism

\begin{tabular}{ll}
\hline \hline Commercial name & NGK honeycomb ceramics (NGK INSULATORS, LTD.) \\
Material & Mullite \\
Outside dimension & $100 \mathrm{H} \times 98 \mathrm{D}(\mathrm{mm})$ \\
Average inside diameter of penetrating core & $2.9 \mathrm{~mm}$ \\
Cross sectional vacancy of honeycomb structure & $73.7 \%$ \\
Porosity & $37 \% \sim 39 \%$ \\
Average pore size & $10 \mu \mathrm{m}$ \\
\hline
\end{tabular}




\section{Chemical analysis and bacterial count}

Ethanol concentration was determined by means of specific gravity. Acetic acid concentration was determined by titration with $0.1 \mathrm{~N}$ sodium hydroxide solution and acetic acid concentration in a product was calculated by the following equation :

Acetic acid concn. $(\%(\mathrm{w} / \mathrm{v}))$

$$
=(A-B) \times 0.6005
$$

$A: \mathrm{m} l$ of $0.1 \mathrm{~N} \mathrm{NaOH}$ per $1 \mathrm{~m} l$ of product

$B: \mathrm{m} l$ of $0.1 \mathrm{~N} \mathrm{NaOH}$ per $1 \mathrm{~m} l$ of substrate

Organic acid composition was determined by high performance liquid chromatography (Shimadzu LC-4A). A $1 \sim 5 \mu l$ of sample was injected into a SCR-101 $\mathrm{H}$ column maintained at $60^{\circ} \mathrm{C}$, eluted with water $-\mathrm{HClO}_{4}$ solution $(\mathrm{pH}$ 1.8) at a flow rate of $0.7 \mathrm{ml} / \mathrm{min}$, and detected at UV $210 \mathrm{~nm}$ (quantification: absolute determination method).

Total bacterial cell number was determined by counts in a Bacteria Counting Chamber (Erma Co.) under a microscope (Olympus Vanox-AHBS).
Conversion ratio of acetic acid from ethanol was determined by the following equation :

$$
\begin{aligned}
& \text { Conversion ratio }(\%)=\frac{D \times 46.07}{C \times 0.793 \times 60.05} \\
& \quad \times 100
\end{aligned}
$$

$C$ : ethanol concn. in substrate $\%(\mathrm{v} / \mathrm{v})$

$D:$ acetic acid concn. in product \% (w/v)

\section{Results and Discussion}

Continuous production of vinegar under the open condition

The results were shown in Table 2. The maximum concentration of acetic acid obtained was $8.10 \%$ from the substrate of $8.41 \%(\mathrm{w} / \mathrm{v})$ ethanol, and the maximum conversion ratio was $81.1 \%$ when the ethanol concentration in substrate was $4.73 \%(\mathrm{w} / \mathrm{v})$ at the residence time of 36 hours.

The conversion ratio was lowered with increasing ethanol concentration of substrate. It was considered to be caused by vaporization of ethanol in the substrate and of acetic acid in

Table 2 Results of three types of fermentation

\begin{tabular}{cccccc}
\hline \hline & $\begin{array}{l}\text { Ethanol } \\
\text { concn. } \\
\text { in substrate } \\
\%(\mathrm{w} / \mathrm{v})\end{array}$ & $\begin{array}{c}\text { Residence } \\
\text { time }\end{array}$ & $\begin{array}{c}\text { Final acetic } \\
\text { acid concn. } \\
\%(\mathrm{~h})\end{array}$ & $\begin{array}{c}\text { Conversion } \\
\text { ratio** }\end{array}$ & $\begin{array}{c}\text { Oxygen } \\
\text { supply }^{* * *}\end{array}$ \\
\hline $\begin{array}{c}\text { Open condition } \\
\text { with }\end{array}$ & 4.73 & 36 & 4.99 & 81.1 & - \\
synthetic medium & 6.82 & 36 & 6.59 & 74.3 & - \\
& 8.41 & 36 & 8.10 & 74.1 & - \\
\hline & 8.80 & 36 & 8.00 & 70.2 & - \\
Closed condition & 4.73 & 36 & 5.64 & 91.9 & 1.21 \\
with & 5.55 & 36 & 6.71 & 92.9 & 1.11 \\
synthetic medium & 7.93 & 36 & 7.21 & 93.3 & - \\
& 4.28 & 36 & 7.78 & 80.0 & 1.07 \\
& 6.34 & 48 & 5.46 & 97.8 & - \\
& 7.24 & 48 & 8.11 & 98.3 & - \\
\hline Closed condition & 7.32 & 48 & 8.39 & 89.2 & - \\
with & 4.72 & 40 & 7.38 & 77.4 & - \\
orange wine & 6.00 & 27 & 5.96 & 97.0 & 0.97 \\
\hline
\end{tabular}

*Ethanol \% (v/v) $\times 0.793$

${ }^{* *}$ Calculated by the Equation (2)

"** Oxygen supplied/Oxygen theoretically required to completely oxidize ethanol in substrate 
the product because only a small fraction of ethanol remained in the product in spite of the low conversion ratio.

For example, with a substrate of $6.82 \%$ $(w / v)$ ethanol, conversion ratio to acetic acid was only $74.3 \%$, and ethanol concentration in the product was below $0.8 \%(\mathrm{w} / \mathrm{v})$. Then, in order to prevent the vaporization of ethanol, we operated the bioreactor under the closed condition.

Continuous production of vinegar under the closed condition

The results of continuous production of vinegar under the closed condition were similarly shown in Table 2.

And organic acid composition of the product is shown in Table 3 .

The maximum concentration of acetic acid obtained was $8.39 \%$ from the substrate containing $7.24 \%(\mathrm{w} / \mathrm{v})$ ethanol, and the maximum conversion ratio of acetic acid from ethanol was $98.3 \%$ when the synthetic medium was used. The conversion ratio of $90 \%$ or higher was obtained in the synthetic medium containing ethanol at $5.93 \%(\mathrm{w} / \mathrm{v})$ or lower with the residence time of 36 hours and up to $6.34 \%$ $(\mathrm{w} / \mathrm{v})$ at 48 hours of residence time.

Unshu mandarine orange vinegar with $7.21 \%$ of acetic acid was obtained from the substrate of $6.00 \%(\mathrm{w} / \mathrm{v})$ of ethanol at 27 hours of residence time (conversion ratio, 92.4\%) and the amount of residual ethanol in the product was below $0.1 \%(\mathrm{w} / \mathrm{v})$. Number of bacterial cells in the effluent was stayed at $7 \sim 9 \times 10^{8} /$ $\mathrm{m} l$.

However, the concentration of acetic acid in the product and the conversion ratio to acetic acid were evidently lowered with the ethanol concentration in the substrate of $7.24 \%(\mathrm{w} / \mathrm{v})$ or higher.

The flavor and taste of the vinegar produced in the bioreactor were normal as far as it was produced under conditions when conversion ratio was held higher than $89.2 \%$.

Whereas the amount of oxygen supplied was considered to be enough to oxidize ethanol in the substrate as shown in Table 2, the amount of residual ethanol below $0.8 \%(\mathrm{w} / \mathrm{v})$ was observed in the product in any cases of the closed condition.

Therefore, it is considered that acetic acid was transformed to other compounds such as esters or degraded to carbondioxide with peroxidation by acetic acid bacteria.

From now, it might be necessary to experiment with the acetic acid bacteria more resistive against acetic acid for the production of vinegar with high acetic acid concentration.

The continuous production of vinegar has been carried out by use of this bioreactor for three years with no deterioration or trouble of the performance.

\section{Acknowledgment}

We express appreciations to NGK INSULATORS, LTD. for their supply of the honeycomb

Table 3 Organic acids composition of the product fermented in the closed condition

\begin{tabular}{lccccc}
\hline \multirow{2}{*}{ Kind } & \multicolumn{3}{c}{ Organic acid composition \%(w/v) } & Titrated \\
& $\begin{array}{l}\text { Acetic } \\
\text { acid }\end{array}$ & $\begin{array}{l}\text { Citric } \\
\text { acid }\end{array}$ & $\begin{array}{l}\text { Malic } \\
\text { acid }\end{array}$ & $\begin{array}{l}\text { Succinic } \\
\text { acid }\end{array}$ & acidity (ml) \\
\hline $\begin{array}{l}\text { Vinegar produced from a } \\
\text { synthetic media }\end{array}$ & 6.80 & tr. & 0.1 & 0.0 & 11.54 \\
$\begin{array}{l}\text { Vinegar produced from } \\
\text { Unshu mandarine orange } \\
\text { wine }\end{array}$ & 5.96 & 0.6 & 0.1 & 0.1 & 11.03 \\
$\begin{array}{l}\text { Unshu mandarine orange } \\
\text { wine (Original substrate } \\
\text { solution) }\end{array}$ & 0.00 & 0.6 & 0.1 & 0.3 & 0.97 \\
\hline
\end{tabular}

$* \mathrm{~m} l$ of $0.1 \mathrm{~N} \mathrm{NaOH} / 1 \mathrm{~m} l$ of sample 
ceramics.

\section{References}

1) KenNedy, J.F., Humphres, J.D., BARKER, S.A. and Greenshields, R.N. : Enzyme Microb. Technol., 2, 209 (1980).

2) Osuga, J., MoRI, A. and Kato, J.: J. Ferment. Technol., 62, 139 (1984).

3) SAEKI, A.: Nippon Shokuhin Kogyo Gakkaishi, 37191 (1990).

4) GHOMMIDH, C., NAVARRo, J.M. and Durand, G. : Biotechnol. 24, 605 (1982).

5) Okuhara, A.: J. Ferment. Technol., 63, 57 (1985).

6) Hiramitsu, T., Takada, M. and Fujita, T. : Japanese Patent Laying Open No. S. 64-67176 (1989).

7) Hiramitsu, T. : Reports of the Gifu Prefectural Industrial Research Technical Center, 20, 26 (1988).

(Received Sep. 19, 1990)
多孔質セラミックスを担体としたパイオリアクター による食酢の連続生産

高田満郎* - 平光 武*

*岥阜県工業技術センター

（干501-61 岐阜県羽島郡笠松町北及 47)

多孔質セラミックスを酢酸菌 Acetobacter aceti (IFO-3284) の担体とした 2 塔からなるバイオリアクタ 一で，エタノールを含む合成培地及び温州ミカンワイン から酢酸を連続発酵した：発酵は閉鎖系あるいは開放系, 合成培地のエタノール濃度は $4.28 \sim 8.80 \mathrm{w} / \mathrm{v} \%$ の範 囲で行った．開放系ではエタノール濃度 $8.41 \mathrm{w} / \mathrm{v} \%$ の とき $8.10 \%$ の最高濃度の酢酸を得た．閉鎖系ではエ夕 ノール濃度 $7.24 \mathrm{w} / \mathrm{v} \%$ のとき最高濃度 $8.39 \%$ であっ た.エタノールから酢酸への変换率は開放系で最高 $81.1 \%$ ，閉鎖系で最高 $98.3 \%$ であった. 同様に, 閉鎖 系で発酵された温州ミカンワインは香味に問題がなかっ た。なお，閉鎖系における酸素の供給量は合成培地中の エタノールを酸化するのに十分な量であった。 